\title{
The Impact of Financial Technology on the Operational Efficiency of Traditional Commercial Banks
}

\author{
Chen Zhao \\ School of Mathematics and Quantitative Economics, Shandong university of finance and \\ economics, Jinan, China \\ sdufezhaochen@163.com
}

\begin{abstract}
This paper uses the annual report data of 16 traditional commercial banks from 2015 to 2019, uses DEA-Malmquist index method, selects fixed assets, number of employees and operating expenses as input variables, and selects net profit and deposit loan ratio as output variables to do an empirical research on the impact of financial technology on the operating efficiency of traditional commercial banks. The results show that: commercial banks generally adapt to the changes in the financial market brought by the rapid development of financial technology, and use financial technology to improve their operational efficiency; the operational efficiency of 16 commercial banks increased in last five years, but there are differences among them. Generally speaking, the performance of local banks is better than that of joint-stock banks, and the performance of joint-stock banks is better than that of state-owned commercial banks. The average operating efficiency of commercial banks in the past five years is relatively low, mainly due to the low efficiency of science and technology application and the slow efficiency of science and technology renewal. Based on the above empirical findings, this paper makes important recommendations for bank growth, policy support, and personnel training in the context of rapid financial technology development. This paper may provide some insight into China's banking industry's efficient growth.
\end{abstract}

Keywords: Financial Technology; Commercial Bank; Operation Efficiency; DEA-Malmquist Index.

\section{Introduction}

Financial technology generally refers to new business models, new technology applications and new product services driven by emerging technologies such as big data, Internet, blockchain, cloud computing, artificial intelligence and so on, which have a significant impact on the financial market and the supply of financial services. 2015 is a key year for the development of financial science and technology in China. The State Council and the Central Bank successively issued the "State Council's Guiding Opinions on actively promoting the "Internet plus" action" and "the guiding opinions on promoting the healthy development of Internet finance", which formally incorporated the development of financial technology into the regulatory framework, and put forward a series of policies and measures to encourage innovation and support the steady development of financial technology. Financial science and technology has changed from barbaric and rapid development stage to standardized and rapid development stage. In 2017, the Central Bank officially established the Financial Science and Technology Committee, which aims to do a good job in strategic planning and policy guidance in China's financial science and technology, and provide appropriate guidance of new technologies in the field of finance.

The increasingly mature and rapid development of financial technology not only changes people's trading habits and China's financial structure, but also deepens its influence on traditional commercial banks.

The impacts of financial technology on commercial banks can be divided into three aspects: liability end, asset end and intermediary business. On the debt end, against the backdrop of the development in financial technology, the financial products have the characteristics of convenient transaction and low transaction cost, so they attract the savings deposits of residents, resulting in the reduction of retail deposits at the debt end of banks, and compressing the profit space of banks. On the asset end, blockchain, artificial intelligence and big data effectively reduce information asymmetry, which provides digital opportunities for commercial banks to adjust the credit structure 
and term structure of loans. In terms of intermediary business, intelligent investment advisory, blockchain, mobile banking and online banking have played an active role in reducing cost, improving efficiency and expanding business for commercial banks, but at the same time, the development of financial technology has also occupied the intermediary business market of banks to a certain extent. It can be seen that the rapid development of financial technology brings opportunities as well as challenges to traditional commercial banks. Therefore, in the context of the rapid development of financial technology, research on the operational efficiency of commercial banks, which are in the dominant position of the financial industry, is of great significance to the development of commercial banks and the future development of China's financial industry.

\section{Literature Review}

At present, domestic scholars' research on the impact of financial technology on the efficiency of traditional commercial banks is mainly divided into two stages. In the first stage, most scholars define science and technology as the form of Internet finance, and have not yet formed the concept of financial technology. The research on the impact of financial technology on bank operation efficiency mainly focuses on Internet finance. Internet finance was first put forward by Xie. Its connotation is to use Internet technology and information communication technology to realize financing, payment and investment. At this stage, most scholars mainly study the impact of Internet Finance on the liability side and asset side of banks, and draw relevant conclusions on the impact of financial technology on the efficiency of commercial banks by means of quantitative or qualitative analysis. Zhou and Peng (2018) measured the operation efficiency of commercial banks by using the Threestage DEA method excluding external influence, and reflected the impact of Internet Finance on the operational efficiency of commercial banks in the context of the Internet Finance boom, and concluded that the negative impact of Internet Finance on the operational efficiency of most traditional commercial banks is greater, there is still much room for efficiency improvement in banks. Qiu et al. (2018) from the perspective of financial technology promoting the marketization of deposit interest rate, analyzed its impact on the debt side and asset side of banks, and concluded that under the influence of financial technology, the proportion of banks accounted for less, the proportion of residents' deposits increased, and the proportion of interbank liabilities increased. At the same time, the change of liability cost led to banks preferring to choose high-risk assets to make up for losses. Cang et al. (2016) used the DEA method to analyze the impact of technology on the operational efficiency of commercial banks with the third-party payment as the influencing factor, and concluded that financial technology has a positive effect on the productivity of banks. Liang (2017) also studied the impact of the Internet on banks from the perspective of third-party Internet mobile payment, and concluded that although the impact of Internet mobile payment on commercial banks of different sizes is different, it is mainly a positive impact. Wang Chun (2020) used the random panel model to study the positive and negative impact mechanism of the third-party payment on the operational efficiency of commercial banks from the perspective of the third-party payment of Internet finance, and concluded that the third-party payment has a negative impact on the operation ability and security of banks, and has a positive impact on the development ability of commercial banks. In the second stage, most scholars not only focus on Internet finance, but also expand the research content. Hao (2020) pointed out that Internet finance is one aspect of financial technology. However, he did not make an in-depth analysis on the impact of financial technology on commercial banks, only made a simple qualitative analysis, and concluded that financial technology can inject vitality into commercial banks. From the perspective of financial technology theory, Cao (2020) studies the impact of financial technology on the efficiency of commercial banks, and concludes that the impact of financial technology on commercial banks in terms of increasing customer range, reducing transaction costs and improving internal management efficiency is a positive conclusion. On the basis of Internet payment and mobile payment, $\mathrm{Li}$ (2020) added research on cloud computing, big data and artificial intelligence, and concluded that Internet payment, mobile payment and cloud computing 
bring positive effects to commercial banks, while big data and artificial intelligence will bring negative effects. Lu (2020) used Malmquist index to measure the operational efficiency of commercial banks, and concluded that under the background of the development of financial technology, commercial banks' rational use of financial technology can bring positive effects to commercial banks. Liu and Jiang (2020) pointed out the connotation of more comprehensive financial technology, but did not specifically quantify the impact of various factors on commercial banks, only made an overall analysis, and concluded that financial technology has a positive impact on the operational efficiency of commercial banks.

Financial technology covers a wide range of content, and Internet finance is only a branch of financial technology. At present, the research on the impact of financial technology on commercial banks mainly focuses on the Internet Finance Based on mobile payment and Internet payment. Although the scope of research has been expanded in some later studies, it mainly focuses on qualitative analysis or quantitative analysis to reflect the impact of financial technology on the efficiency of commercial banks, without further quantitative analysis on the main factors. Based on the research of most scholars in this field, this paper analyzes the impact of financial technology with big data, blockchain, artificial intelligence and Internet as the core on the operational efficiency of commercial banks.

\section{Empirical Analysis}

\subsection{Construction of DEA Malmquist Index Model}

\subsubsection{DEA Model}

DEA model, namely data envelopment analysis model, is used to evaluate the relative effectiveness among decision-making units. It has absolute advantage in evaluating the efficiency of decision-making units with multi output and multi-input. DEA model is widely used in finance, economy, project evaluation and other fields.

Suppose that for $n$ DMUs, each DMU has $m$ inputs and s outputs $x_{i j}$ Represents the i-th input of the $\mathrm{j}$-th decision variable to $y_{t j}$ Represents the $\mathrm{t}$-th output of the $\mathrm{j}$-th decision-making variable $v_{t}$ Represents the weight of the $\mathrm{i}^{\text {th }}$ input, $u_{t}$ Then the efficiency evaluation index of DMU $\mathrm{J}$ is

$$
h_{j}=\frac{\sum_{t=1}^{s} u_{t} y_{t j}}{\sum_{i=1}^{m} v_{t} x_{i j}}
$$

\subsubsection{Malmquist Index}

The traditional DEA model can only measure the relative efficiency of the book abuse unit at a certain time, but the empirical research on the impact of financial technology on the operational efficiency of traditional commercial banks is based on the study of dynamic changes in a continuous period of time, which is contradictory to the use conditions of DEA model. The combination of Malmquist index and DEA model can measure the dynamic production efficiency of cross period data, In addition, it is not necessary to assume the rationality and effectiveness of the parameter estimation in advance, and do not need to seek the function form of the production frontier in advance, so as to avoid the error caused by the wrong function setting.

(1) Definition of Malmquist Index

Malmquist index was firstly put forward by Malmquist in 1953. Caves et al began to apply Malmquist index to measure efficiency in 1982.

Suppose there are $\mathrm{n}$ decision-making units. Each decision-making unit has $\mathrm{m}$ inputs and $\mathrm{n}$ outputs at time $t, D_{i}^{t}\left(x^{t}, y^{t}\right)$ is the distance function at time $t$ for $\left(x^{t}, y^{t}\right)$. The distance function for $t+1$ is $D_{i}^{t+1}\left(x^{t}, y^{t}\right)$.

In stage $t$, the change of technical efficiency from $t$ to $t+1$ is as follows: 
Volume 15 (2021)

$$
M_{i}^{t}=\frac{D_{i}^{t}\left(x^{t}, y^{t}\right)}{D_{i}^{t}\left(x^{t+1}, y^{t+1}\right)}
$$

Under the technical condition of $t+1$, the change value of technical efficiency from $t$ to $t+1$ is as follows:

$$
M_{i}^{t+1}=\frac{D_{i}^{t+1}\left(x^{t}, y^{t}\right)}{D_{i}^{t+1}\left(x^{t+1}, y^{t+1}\right)}
$$

The change of production efficiency from $t$ to $t+1$ is as follows:

$$
M_{i}=\left[\frac{\mathrm{D}_{\mathrm{i}}^{\mathrm{t}+1}\left(\mathrm{x}^{\mathrm{t}}, \mathrm{y}^{\mathrm{t}}\right)}{\mathrm{D}_{\mathrm{i}}^{\mathrm{t}+1}\left(\mathrm{x}^{\mathrm{t}+1}, \mathrm{y}^{\mathrm{t}+1}\right)} \times \frac{\mathrm{D}_{\mathrm{i}}^{\mathrm{t}}\left(\mathrm{x}^{\mathrm{t}}, \mathrm{y}^{\mathrm{t}}\right)}{\mathrm{D}_{\mathrm{i}}^{\mathrm{t}}\left(\mathrm{x}^{\mathrm{t}+1}, \mathrm{y}^{\mathrm{t}+1}\right)}\right]^{\frac{1}{2}}
$$

(2) Malmquist Exponential Decomposition

Fare R et al decompose Malmquist index into technical efficiency index (Effch) and technological progress index (Tech), in which technical efficiency index can be further decomposed into pure technical efficiency index (Pech) and scale efficiency index (sech), and efficiency index can be shown as:

$$
\operatorname{Effch}=\frac{D_{i}^{t+1}\left(x^{t+1}, y^{t+1}\right)}{D_{i}^{t}\left(x^{t}, y^{t}\right)}
$$

Effch $>1$ indicates that technical efficiency increases with time, while Effch $<1$ indicates that technical efficiency decreases with time. The index of technological progress can be expressed as:

$$
\text { Tech }=\left[\frac{D_{i}^{t}\left(x^{t}, y^{t}\right)}{D_{i}^{t+1}\left(x^{t}, y^{t}\right)} \times \frac{D_{i}^{t}\left(x^{t+1}, y^{t+1}\right)}{D_{i}^{t+1}\left(x^{t+1}, y^{t+1}\right)}\right]^{\frac{1}{2}}
$$

Tech reflects the change of the frontier of $t+1$ period relative to that of $t$ period.

In conclusion, the Malmquist index from $t$ stage to $t+1$ stage can be decomposed into

$$
\begin{gathered}
M_{i}=\operatorname{TFP}=\left(x^{t+1}, y^{t+1} ; x^{t}, y^{t}\right) \\
=\left[\frac{D_{\mathrm{i}}^{\mathrm{t}+1}\left(\mathrm{x}^{\mathrm{t}}, \mathrm{y}^{\mathrm{t}}\right)}{\mathrm{D}_{\mathrm{i}}^{\mathrm{t}+1}\left(\mathrm{x}^{\mathrm{t}+1}, \mathrm{y}^{\mathrm{t}+1}\right)} \times \frac{\mathrm{D}_{\mathrm{i}}^{\mathrm{t}}\left(\mathrm{x}^{\mathrm{t}}, \mathrm{y}^{\mathrm{t}}\right)}{\mathrm{D}_{\mathrm{i}}^{\mathrm{t}}\left(\mathrm{x}^{\mathrm{t}+1}, \mathrm{y}^{\mathrm{t}+1}\right)}\right]^{\frac{1}{2}} \\
=\frac{\mathrm{D}_{\mathrm{i}}^{\mathrm{t}+1}\left(\mathrm{x}^{\mathrm{t}+1}, \mathrm{y}^{\mathrm{t}+1}\right)}{\mathrm{D}_{\mathrm{i}}^{\mathrm{t}}\left(\mathrm{x}^{\mathrm{t}}, \mathrm{y}^{\mathrm{t}}\right)}\left[\frac{\mathrm{D}_{\mathrm{i}}^{\mathrm{t}}\left(\mathrm{x}^{\mathrm{t}}, \mathrm{y}^{\mathrm{t}}\right)}{\mathrm{D}_{\mathrm{i}}^{\mathrm{t}+1}\left(\mathrm{x}^{\mathrm{t}}, \mathrm{y}^{\mathrm{t}}\right)} \times \frac{\mathrm{D}_{\mathrm{i}}^{\mathrm{t}}\left(\mathrm{x}^{\mathrm{t}+1}, \mathrm{y}^{\mathrm{t}+1}\right)}{\mathrm{D}_{\mathrm{i}}^{\mathrm{t}+1}\left(\mathrm{x}^{\mathrm{t}+1}, \mathrm{y}^{\mathrm{t}+1}\right)}\right]^{\frac{1}{2}} \\
=\mathrm{Effch} \times \text { Tech }=(\text { Pech } \times \text { Sech }) \times \text { Tech }
\end{gathered}
$$

(3) Economic Meanings of Malmquist Index

Malmquist index is a measure of the dynamic change from $t$ to $t+1$, which is replaced by $M$ below.

1) When $M>1$, Malmquist index increased from $t$ to $t+1$, and the efficiency increased.

2) When $M=1$, Malmquist index is constant from $t$ to $t+1$, and efficiency remains unchanged.

3) When $M<1$, Malmquist index decreases from $t$ to $t+1$, and efficiency decreases.

\subsection{Data Selection}

At present, most scholars study the efficiency of commercial banks from the perspective of input and output. The main methods are production method, intermediary method, user cost method and 
added value method. Intermediary law can accurately and scientifically reflect the operation of commercial banks after appropriate adjustment of data. Therefore, starting from the function of financial intermediary of banks, this paper selects input variables: fixed assets (x1), number of employees (x2), operating expenses (x3), output variables: net profit (Y1), deposit loan ratio (Y2), and analyzes the changes of business efficiency of commercial banks under the background of financial technology from 2015 to 2019.

Table 1. Efficiency Evaluation Index System

\begin{tabular}{|c|c|c|c|}
\hline Category & Variable & Indicator & Meaning \\
\hline \multirow{3}{*}{$\begin{array}{c}\text { Input } \\
\text { variable }\end{array}$} & $\mathrm{X} 1$ & fixed assets & $\begin{array}{l}\text { The value of assets that play a long-term role in the process of } \\
\text { bank operation is gradually transferred to the product cost with } \\
\text { the bank's business activities }\end{array}$ \\
\hline & $\mathrm{X} 2$ & $\begin{array}{l}\text { Number of } \\
\text { employees }\end{array}$ & The input of bank manpower cost \\
\hline & $\mathrm{X} 3$ & $\begin{array}{l}\text { Operating } \\
\text { expenses }\end{array}$ & $\begin{array}{l}\text { It is pointed out that all the financial business of the bank is the } \\
\text { main component of the bank cost }\end{array}$ \\
\hline \multirow{2}{*}{$\begin{array}{c}\text { Output } \\
\text { variable }\end{array}$} & Y1 & Net profit & $\begin{array}{l}\text { The balance of the bank's income after deducting expenses and } \\
\text { taxes }\end{array}$ \\
\hline & $\mathrm{Y} 2$ & $\begin{array}{l}\text { Deposit loan } \\
\text { ratio }\end{array}$ & $\begin{array}{l}\text { The higher the loan / deposit ratio, the better the profitability of } \\
\text { the bank }\end{array}$ \\
\hline
\end{tabular}

\subsection{Data Sources}

In order to study the impact of financial technology on the operational efficiency of commercial banks, this paper selects the panel data of 16 commercial banks from 2015 to 2019 as the research data. The 16 commercial banks are BANK OF CHINA, CHINA MINSHENG BANK, BANK OF COMMUNICATIONS, AGRICULTURAL BANK OF CHINA, CHINA CONSTRUCTION BANK, CHINA MERCHANTS BANK, SPD BANK, INDUSTRIAL AND COMMERCIAL BANK OF CHINA, CHINA EVERBRIGHT BANK, BANK OF BEIJING, HUA XIA BANK, PING AN BANK, BANK OF NANJING, BANK OF NINGBO and INDUSTRIAL BANK. The data comes from the annual reports of banks. Since 2015, China has strengthened the market supervision of financial technology, and commercial banks have gradually adapted to the changes in the market environment brought about by financial technology. Therefore, this stage of research can better reflect the impact of financial technology on the operational efficiency of traditional commercial banks under the rapid and orderly development of financial technology in China.

\subsection{Descriptive Statistics of Each Variable}

Table 2. Descriptive Statistics of Variables

\begin{tabular}{|c|c|c|c|c|}
\hline variable & mean & standard deviation & Maximum & minimum \\
\hline $\mathrm{X} 1$ & 68806238725 & 77731293949 & 253525000000 & 3420258000 \\
\hline $\mathrm{X} 2$ & 134442.9 & 159636.6703 & 503082 & 7390 \\
\hline $\mathrm{X} 3$ & 137425888912.50 & 116792412411.38 & 464596000000 & 11498194000 \\
\hline $\mathrm{Y} 1$ & 86780399488 & 87725439288 & 313361000000 & 6566991000 \\
\hline $\mathrm{Y} 2$ & 0.7192 & 0.1281 & 1.0900 & 0.4804 \\
\hline
\end{tabular}

\subsection{Analysis of Empirical Results}

\subsubsection{Analysis of Operational Efficiency of Banks}

Taking bank net profit and deposit loan ratio as output variables, fixed assets, number of employees and operating expenses as input variables, Malmquist index of each bank is calculated by decp2.1 software. The results are shown in Table 3 and Figure 1. From Table 3 and Figure 1, we can clearly see the operating efficiency of each bank from 2015 to 2019. Based on this, we can draw the following judgment: 
On the whole, the total factor productivity of the 16 banks is greater than 1 , which indicates that the average annual growth of the 16 commercial banks in the past five years is positive, and their operational efficiency has improved. This shows that since 2015, commercial banks have generally adapted to the changes in the financial market caused by financial technology, and have used financial technology to improve their operational efficiency.

In terms of commercial banks, the average total factor productivity of 16 commercial banks is 1.207. The total factor productivity of five state-owned commercial banks, including Bank of China, China Construction Bank, Agricultural Bank of China, industrial and Commercial Bank of China, and Bank of communications of China are all lower than the average value. In joint-stock banks, except China MinSheng Bank, China Merchants Bank and Ping An Bank, the total factor productivity of other banks is higher than the average value, and the urban commercial banks are higher than the average value. Under the background of the rapid development of financial technology, the performance of city commercial banks is better than that of joint-stock commercial banks, and that of joint-stock banks is better than that of state-owned commercial banks. This shows that the technological innovation brought about by financial technology makes the commercial banks have differences in operating efficiency, which is more conducive to the improvement of business efficiency.

From the point of view of state-owned banks, the reason why their TFP is lower than that of jointstock banks may be that the steady management attitude and inherent system of state-owned banks lead to the slower reaction speed of state-owned banks to the development of financial science and technology than that of joint-stock banks and city commercial banks, and they cannot transform the development of financial technology into their own operational advantages in time, As a result, its operating efficiency is lower than the other two types of banks. From the perspective of joint-stock commercial banks, the reason why their operating efficiency is lower than that of city commercial banks may be that the operation structure of city commercial banks is more flat and smaller. Under the background of the rapid development of financial technology, city commercial banks transform more rapidly, and can quickly seize the new opportunities to improve the operational efficiency of banks under the rapid development of financial technology.

To sum up, under the background of the rapid development of financial technology, the operational efficiency of banks is generally improved, but there are differences among different types of commercial banks. This phenomenon is mainly due to the differences in management attitude, management system and bank volume among different banks, which leads to the difference in the reaction speed of different commercial banks to the development of financial technology.

Table 3. Total Factor Productivity Analysis of Banks

\begin{tabular}{|c|c|c|c|c|c|}
\hline Bank & Effch & Techch & Pech & Sech & Tfpch \\
\hline CHINA MINSHENG BANK & 0.962 & 1.124 & 1.000 & 0.962 & 1.082 \\
\hline BANK OF CHINA & 1.007 & 1.134 & 1.006 & 1.000 & 1.142 \\
\hline BANK OF COMMUNICATIONS & 0.979 & 1.190 & 0.982 & 0.998 & 1.165 \\
\hline AGRICULTURAL BANK OF CHINA & 0.998 & 1.184 & 1.000 & 0.998 & 1.182 \\
\hline CHINA CONSTRUCTION BANK & 1.000 & 1.188 & 1.000 & 1.000 & 1.188 \\
\hline CHINA MERCHANTS BANK & 1.000 & 1.162 & 1.000 & 1.000 & 1.162 \\
\hline SPD BANK & 1.006 & 1.243 & 1.000 & 1.006 & 1.250 \\
\hline INDUSTRIAL AND COMMERCIAL BANK OF CHINA & 0.987 & 1.186 & 1.000 & 0.987 & 1.171 \\
\hline CHINA EVERBRIGHT BANK & 0.979 & 1.231 & 0.980 & 0.999 & 1.205 \\
\hline CHINA CITIC BANK & 0.989 & 1.317 & 0.986 & 1.004 & 1.303 \\
\hline BANK OF BEIJING & 0.999 & 1.252 & 1.005 & 0.994 & 1.251 \\
\hline HUA XIA BANK & 1.007 & 1.269 & 1.007 & 1.000 & 1.278 \\
\hline PING AN BANK & 0.994 & 1.200 & 0.993 & 1.001 & 1.192 \\
\hline BANK OF NANJING & 1.011 & 1.205 & 1.000 & 1.011 & 1.218 \\
\hline BANK OF NINGBO & 1.000 & 1.278 & 1.000 & 1.000 & 1.278 \\
\hline INDUSTRIAL BANK & 1.000 & 1.262 & 1.000 & 1.000 & 1.262 \\
\hline average & 0.995 & 1.213 & 0.997 & 0.997 & 1.207 \\
\hline
\end{tabular}




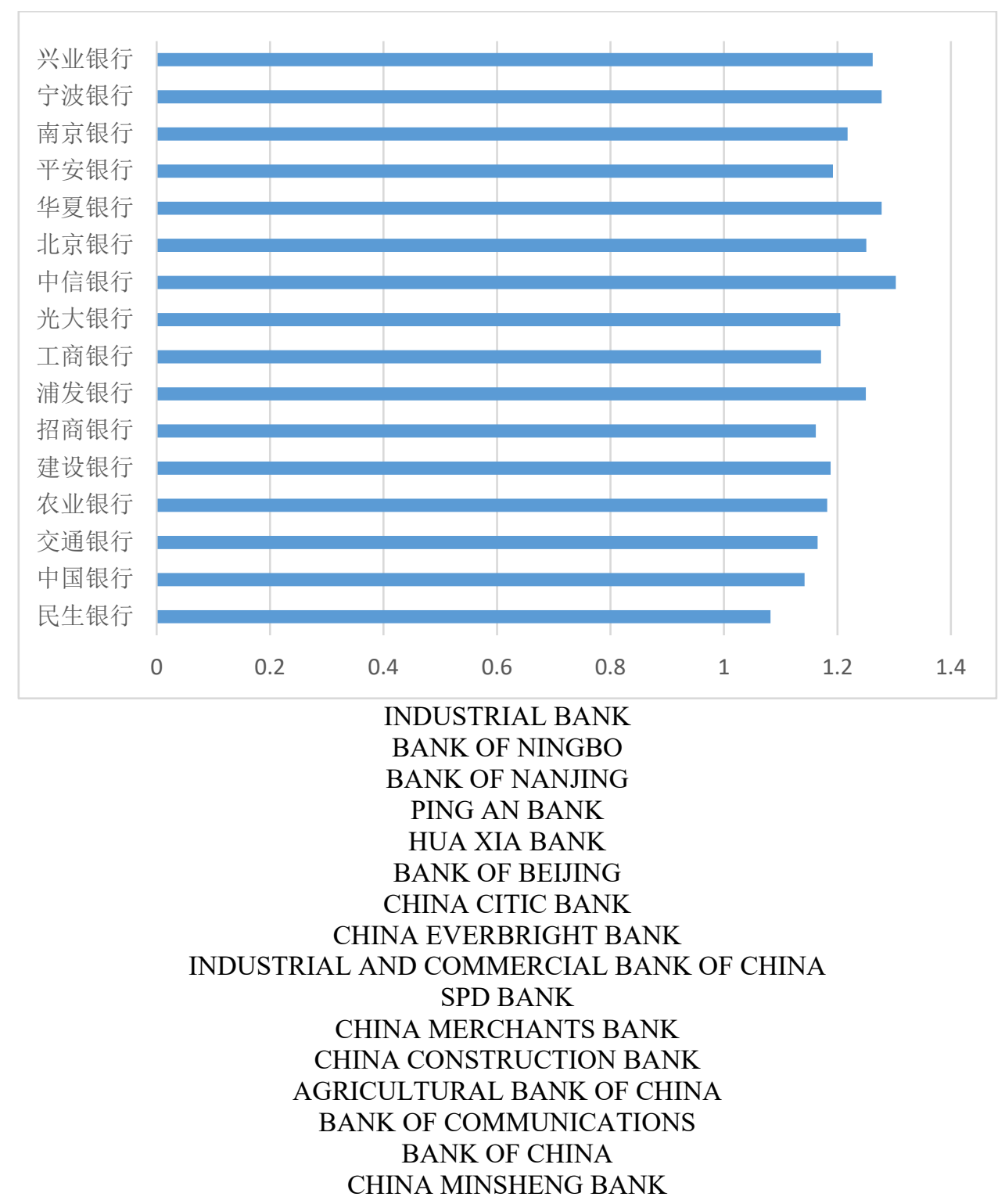

Figure 1. Bar Chart of Total Factor Productivity of Banks

\subsubsection{Analysis on the Annual Efficiency of Commercial Banks}

Table 4 and Figure 2 show the change process of total factor productivity of 16 commercial banks in the five years from 2015 to 2019. Based on this, the following judgment is drawn:

On the whole, the average total factor productivity of the 16 commercial banks is greater than 1 in these five years, which indicates that the average operating efficiency of commercial banks has increased in these five years, which confirms that since 2015, China's commercial banks have gradually adapted to the changes brought about by the development of financial technology and made reasonable policy adjustments. In Table 5, the related products and applications of financial technology of banks in the past five years can be further exemplified by the fact that banks are actively borrowing from fintech.

From different years, the total factor productivity in 2015-2016 and 2016-2017 are 1.144, but the technical efficiency index is significantly different. In 2015-2016, the technical efficiency index is less than 1, and the technical progress index is greater than 1, which indicates that the bank's technical resource utilization efficiency is low. The technical efficiency index of 2016-2017 is greater than 1, but the total factor productivity has not changed due to the decline of technology progress index, which shows that commercial banks are relatively backward in terms of external technological progress in this year. From 2017 to 2018 , the total factor productivity of commercial banks has been greatly improved, which is $13 \%$ higher than that of the previous year, which is mainly due to the 
significant increase of the technology progress index. This phenomenon may be due to the fact that the people's Bank of China announced the establishment of the financial science and Technology Committee in 2017, which clearly proposed to strengthen the application practice of regulatory technology, and actively used big data, artificial intelligence, cloud computing and other technologies to enrich financial regulatory means, so as to enhance the ability to identify, prevent and resolve cross industry and cross market financial risks. Under this guidance, the financial supervision system of banks will be more perfect, and the ability of risk prevention and control will be further strengthened, which will help banks to supervise non-performing loans.

According to the trend of the broken line chart in Figure 2, Figure 2 shows that the technical efficiency index shows a reverse alternating change compared with the technical progress index in different years, which indicates that the improvement of the technical efficiency index lags behind that of the technical progress index. This phenomenon shows that the commercial banks cannot simultaneously improve the utilization ratio of technical resources after the technology is updated, as a result, the improvement of total factor production efficiency is limited.

Table 4. Annual Efficiency of Commercial Banks

\begin{tabular}{|c|c|c|c|c|c|}
\hline year & Effch & Techch & Pech & Sech & Tfpch \\
\hline $2015-2016$ & 0.933 & 1.227 & 0.952 & 0.981 & 1.144 \\
\hline $2016-2017$ & 1.063 & 1.076 & 1.049 & 1.014 & 1.144 \\
\hline $2017-2018$ & 0.897 & 1.476 & 0.995 & 0.884 & 1.297 \\
\hline $2018-2019$ & 1.124 & 1.111 & 0.997 & 1.127 & 1.249 \\
\hline mean & 0.995 & 1.213 & 0.997 & 0.997 & 1.207 \\
\hline
\end{tabular}

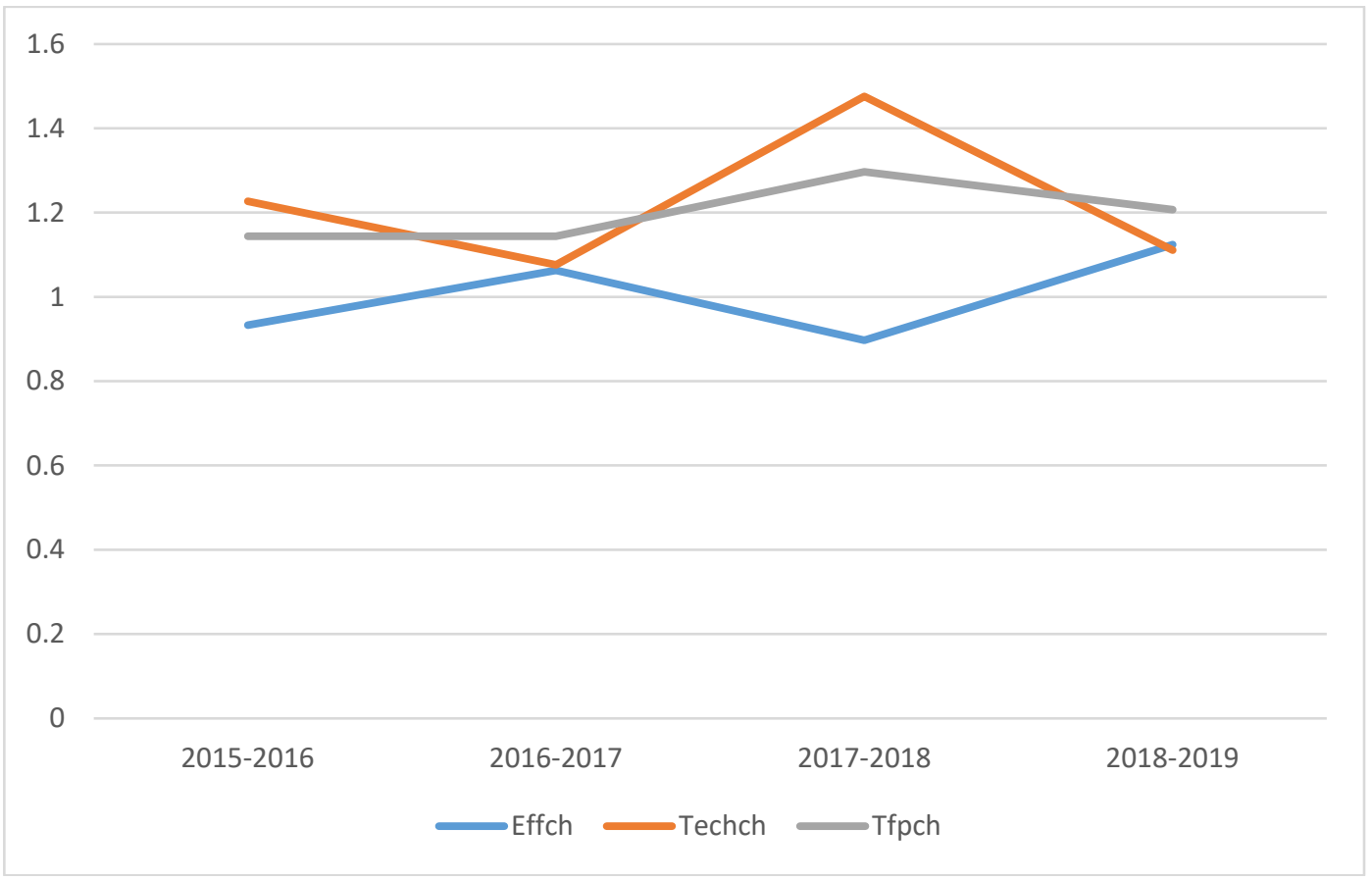

Figure 2. Annual Efficiency Line Chart 
Table 5. Financial Technology Development Achievements of Banks

\begin{tabular}{|c|c|}
\hline & Achievements of financial technology development of banks \\
\hline BANK OF CHINA & $\begin{array}{l}\text { Build big data platform, Bank of China network financial affairs stroke control } \\
\text { system, "BOC huitou", BOC pay, BOC bill and other uniform systems. }\end{array}$ \\
\hline $\begin{array}{c}\text { BANK OF } \\
\text { COMMUNICATIONS }\end{array}$ & $\begin{array}{l}\text { "Pay the bill" app, "I-centered" new mobile banking, "smart payment", intelligent } \\
\text { risk control early warning model, big data strategy model, etc }\end{array}$ \\
\hline $\begin{array}{l}\text { AGRICULTURAL BANK OF } \\
\text { CHINA }\end{array}$ & $\begin{array}{l}\text { IAAs cloud, serverless platform, cloud database, Bi platform, smart contract, } \\
\text { "ABC intelligent investment", "e account opening", "micro Jiedai", etc }\end{array}$ \\
\hline $\begin{array}{l}\text { CHINA CONSTRUCTION } \\
\text { BANK }\end{array}$ & $\begin{array}{l}\text { "5g + smart bank", smart vault, HP financial service platform, overseas full } \\
\text { function banking system, one-stop loan service platform for small and Micro } \\
\text { customers, etc }\end{array}$ \\
\hline CHINA MERCHANTS BANK & $\begin{array}{l}\text { Three AI cloud services, namely, pocket life app, "Tianyun system", "cloud bill", } \\
\text { PAAS, "open API platform", baas platform, intelligent customer service, risk } \\
\text { public opinion and computer vision, are three major AI cloud services }\end{array}$ \\
\hline SPD BANK & $\begin{array}{l}\text { Apibank, 5g + smart outlets, "digital employees", "Puhui cockpit", security } \\
\text { operation center (SOC), "smart small Pu", intelligent account book, digital } \\
\text { transformation of financial products, etc }\end{array}$ \\
\hline $\begin{array}{l}\text { INDUSTRIAL AND } \\
\text { COMMERCIAL BANK OF } \\
\text { CHINA }\end{array}$ & $\begin{array}{l}\text { "Host + open platform" dual core IT architecture platform, smart bank ecosystem } \\
\text { ecos1.0, "ICBC e-wallet", information security operation center cos platform, etc }\end{array}$ \\
\hline $\begin{array}{l}\text { CHINA EVERBRIGHT } \\
\text { BANK }\end{array}$ & $\begin{array}{l}\text { "Sunshine E-Chain", "companion E-Chain", intelligent counter, mobile outward } \\
\text { PDA, sunshine supply chain, "financial technology innovation laboratory", cloud } \\
\text { payment business, "cloud payment", "xinxindai", etc }\end{array}$ \\
\hline CHINA CITIC BANK & $\begin{array}{c}\text { "Mobile card space app", credit card core system "StarCard", all IP open service } \\
\text { platform, AI robot, RPA platform, etc }\end{array}$ \\
\hline BANK OF BEIJING & $\begin{array}{l}\text { "Thousands of people and thousands of faces" financing recommendation model, } \\
\text { "Jingguan +" enterprise mobile app, "Jingxin chain", "palm Jingcai" newsql cloud } \\
\text { database platform, "e-point loan", "Jingzhi AI", risk filter 2.0, etc }\end{array}$ \\
\hline HUA XIA BANK & $\begin{array}{c}\text { "Huacai life" app, "i-mobile", mobile banking, digital credit, "brush face } \\
\text { payment", "platform Tongbao", intelligent investment consultant, intelligent } \\
\text { customer service robot, online loan risk control system, etc }\end{array}$ \\
\hline PING AN BANK & $\begin{array}{c}\text { Orange E-Net, pocket bank, "bank E-Link", Vym, CRS, "Ruyi Bao", "orange } \\
\text { bank" app, smart counter facebank, SAS, "factoring cloud" platform }\end{array}$ \\
\hline BANK OF NANJING & $\begin{array}{c}\text { "Xinkuai", APP innovative application of OCR and other financial technology, } \\
\text { LPR interest rate swap transaction in summit system, national secret } \\
\text { transformation of gold trading settlement system, online customer marketing } \\
\text { management platform, data supply chain service platform }\end{array}$ \\
\hline BANK OF NINGBO & $\begin{array}{l}\text { Small and micro enterprises online "fast audit and quick loan" products, easy to } \\
\text { collect treasure, "wealth manager" app, "foreign exchange golden housekeeper" } \\
\text { app, "bill good housekeeper" app, etc }\end{array}$ \\
\hline INDUSTRIAL BANK & $\begin{array}{c}\text { "Xingshan loan", "process robot (PAR)", face recognition, hall VIP guest } \\
\text { recognition, hall intelligent robot, "e-finance", new generation retail network credit } \\
\text { pre credit model, etc }\end{array}$ \\
\hline CHINA MINSHENG BANK & $\begin{array}{l}\text { Direct bank, "cloud + open mode }+ \text { linker" mode, new version of personal mobile } \\
\text { banking 5.0, "cloud quick loan" and other online loan products, spa platform core } \\
\text { system construction, etc }\end{array}$ \\
\hline
\end{tabular}

\section{Conclusion and Suggestion}

\subsection{Conclusion}

In this paper, DEA-Malmquist index method is used to analyze the data of 16 traditional commercial banks in China from 2015 to 2019.

Firstly, commercial banks have generally adapted to the changes in the financial market by financial technology and used financial technology to improve their operational efficiency since 2015. From 2015 to 2019, the total factor productivity of all 16 commercial banks is greater than 1 , and the average total factor productivity of the 16 commercial banks is also greater than 1 in these five years, indicating that the operating efficiency of commercial banks has been increasing in the past five years. 
Secondly, the operational efficiency of 16 commercial banks has improved from 2015 to 2019, but there are differences among different banks. After 2015, commercial banks have generally adapted to the development of financial technology, and the total factor production efficiency is greater than 1. However, due to the differences in business attitude, management system and bank volume between banks, there are differences in total factor production efficiency of different banks.

Thirdly, the response of commercial banks to technological progress has delaying. Commercial banks cannot simultaneously improve the utilization rate of technical resources after technology update, which leads to the limitation of total factor production efficiency. The index of technical efficiency in different years from 2015 to 2019 shows a inverse alternating change compared with the index of technological progress.

\subsection{Suggestions}

Based on the above conclusions, this paper puts forward some suggestions on bank development, policy support and personnel training.

(1) Banks should strengthen the innovation of financial technology and management concept, and face financial technology bravely. Under the background of the rapid development of financial technology, one of the difficulties of commercial banks is that the reform speed of financial technology is too slow, which leads to the passive state of commercial banks. Therefore, commercial banks should increase investment in capital and manpower in financial science and technology, strengthen cooperation with financial technology companies, and enhance the development and application ability of financial technology products; at the same time, banks should strengthen the innovation of business concepts and abandon the traditional development concept of "the more outlets, the longer the station lines, the better the coverage", they need to change to high efficiency, low cost, personalized, convenient transformation, and fully absorb the essence of the development of financial technology and transform it into its own competitive advantage. Secondly, we should strengthen the training of business personnel and speed up the application ability of financial technology products. One of the reasons why the improvement of bank operation efficiency is limited lies in the low efficiency of technology utilization. The personnel who only master the traditional banking business no longer adapt to the current development situation and will lead to the low efficiency of bank operation. Therefore, the bank should strengthen the staff's business training, so that the staff can keep pace with the times.

(2) The relevant policy institutions should strengthen the support to the financial technology field of commercial banks. For example, we can strengthen the construction of financial science and technology projects by expanding the coverage of financial technology pilot projects in the banking field and spending on the infrastructure of bank financial technology. Secondly, financial technology can be used to build a cross regional, cross system, cross department, cross business and cross market data fusion mechanism to promote data sharing, so as to improve the ability of cross industry and cross market screening, prevention and resolution of cross financial risks, so as to reduce the nonperforming loan rate of commercial banks and promote the better development of commercial banks. Moreover, the era of commercial banks relying on traditional business to obtain high profits has passed. Relevant policy institutions should loosen the ties of commercial banks, encourage and support commercial banks to develop new businesses, and stimulate the vitality of banks properly.

(3) Strengthen the training of financial technology talents. We should pay attention to the cultivation of financial compound talents. With the rapid development of financial technology, the financial field needs more and more financial talents who are proficient in data analysis and Internet technology. At present, the cultivation of financial talents is relatively single, and talents only with pure economic, financial, management and others cannot meet the development of the industry. Colleges and universities should break through the professional barriers and create compound talents under the interdisciplinary of computer, big data and finance. In the process of personnel training in the financial field, we should break through the traditional training concept and actively introduce courses such as data mining, data analysis, computer programming, etc. At the same time, we should 
Volume 15 (2021)

strengthen students' learning in financial current affairs, and guide students to keep close contact with the status of financial market and keep pace with the times.

\section{References}

[1] Li Y. An Empirical Study on the Impact of Financial Technology on the Profitability of China's Listed Commercial Banks [J]. Journal of Natural Science of Hunan Normal University, 2020,43 (05): 83-89.

[2] Liu M., Feng J., \& Jiang W. Regulatory Challenges and Countermeasures of FinTech [J]. West China Finance, 2020 (07): 91-93.

[3] Yang W., Xu H., Tan X., \& Xue X. FinTech and Commercial Bank Efficiency---An Empirical Study Based on DEA Malmquist Model [J]. Studies of International Finance, 2020 (07): 56-65.

[4] Zhou M., \& Chen L. The Efficiency Evaluation of Chinese Commercial Banks Based on DEA-Malmquist Index [J]. Zhejiang Finance, 2020 (06): 12-21.

[5] Hao J. Analysis of the impact of financial technology on traditional commercial banks [J]. Modern Business, 2020 (15): 114-115.

[6] Li Z. Research on the Impact of Financial Technology on the Operational Efficiency of Commercial Banks [D]. Lanzhou University, 2020.

[7] Pu G. Impact of Financial Innovation on Operational Efficiency of Commercial Banks [J]. Journal of Nanjing University of Finance and Economics, 2020 (02): 39-48.

[8] Feng F. Analysis of the Impact of Internet Finance on the Technical Efficiency of Chinese Commercial Banks [D]. Nanjing Normal University, 2019.

[9] Fan L., \& Li J. Empirical Study on the Impact of Internet Finance on Commercial Banks' Technical Change Efficiency [J]. China price, 2019 (02): 58-61.

[10] Zhou C., \& Peng H. Research on the Efficiency of China's Listed Commercial Banks under the Rise of Internet Finance -- Based on the Three-stage DEA Method [J]. Credit Investigation, 2018,36 (12): 72-78.

[11] Qiu H., Huang Y., \& Ji Y. The Impact of Financial Technology on Traditional Bank Behavior: From the Perspective of Internet Financial Management [J]. Financial Research, 2018 (11): 17-29.

[12] Lu L., \& Xu F. Research on Operation Efficiency of China's Commercial Banks under the Background of Financial Technology [J]. Financial Education Research, 2018,31 (05): 33-39.

[13] Wang J. Research on the Efficiency Evaluation of the Combination of Science and Technology Finance in China Based on DEA Malmquist Index [J]. Shanghai Finance, 2018 (08): 92-95.

[14] Wang C. Research on the Impact of Third-Party Payment on the Operational Efficiency of Commercial Banks [D]. Anhui University of Finance and economics, 2018.

[15] Li X., \& Zou K. Discussion on the Connotation of Science and Technology Finance and Policy Suggestions [J]. Financial Theory and Practice, 2018 (03): 1-8.

[16] Yi X. Connotation, Essence and Future Development of Financial Technology: A General Analysis Based on Financial Theory [J]. Jianghai Academic Journal, 2017 (02): 13-20.

[17] Liang Y. Internet Finance's Impact on Commercial Banks: On the Prospective of Third-Party Internet Mobile Payment [J]. Financial Theory \& Practice, 2017 (02): 81-86.

[18] Cang M., Ju L., \& Meng L. Research on the Impact of Internet Finance on the Efficiency of Chinese Commercial Banks [J]. Finance and Economics, 2016 (06): 62-65 + 34. 